\title{
Rantai Pasok Usaha Penggilingan Padi Studi Kasus : UD. Putra Tunggal Kabupaten Kolaka Timur
}

Yuli Purbaningsih ${ }^{*}$, Bahari², Sitti Aida Adha Taridala², dan . Idrus Salam ${ }^{2}$

${ }^{1}$ Universitas Sembilanbelas November Kolaka, Indonesia

2Universitas Halu Oleo, Kendari, Indonesia

*Correspondence author : yoeliyoelan7@gmail.com

\section{Article Info}

Article history:

Received 22 July 2021

Received in revised from 29 July 2021

Accepted 26 October 2021

DOI:

https://doi.org/ 10.32938/ag.v6i4.1421

Keywords:

Gran

Rice

Milling

Supply Chain

\begin{abstract}
Abstrak
This study aims to identify and describe the supply chain system in the rice milling business. This study is an explanatory research. The case study was conducted at UD. Only Son in East Kolaka. The results of this study are, the supply chain system in the rice milling business consists of 2 groups, namely the raw material supply channel (grain) and the product distribution channel (rice). The channel for supplying raw materials (grain) is dominated by the Farmer - Grain Collector - Company channel which has a $50 \%$ share of the total annual purchase volume. Meanwhile, the product distribution channel (rice) is dominated by the Company Wholesaler channel which has a $55 \%$ share of the total annual sales volume. The complexity of the supply chain creates the possibility of potential financial risks. Most of the supply chain in terms of volume and percentage $(>50 \%)$ is traversed by products, namely from farmers, grain traders, UD Putra Tunggal, and wholesalers.
\end{abstract}

\section{Pendahuluan}

Agroindustri atau industri pertanian sebagai bagian integral dari sektor pertanian yang mempunyai kontribusi penting dalam proses industrialisasi di wilayah pedesaan (Suryana, 2014). Membangun agroindustri merupakan salah satu usaha meningkatkan efesiensi faktor pertanian hingga menjadi kegiatan yang sangat produktif. Proses modernisasi pertanian dapat meningkatkan penerimaan nilai tambah sehingga pendapatan ekspor akan lebih besar lagi (Saragih, 2010).

Berdasarkan hal tersebut bahwa, agroindustri atau subsistem pengolahan hasil pertanian merupakan suatu usaha dibidang pertanian dan suatu sistem yang disebut agribisnis, yaitu suatu sistem bisnis yang mampu mendorong pembangunan (Padangaran, 2016a). Salah satu upaya pemenuhan kebutuhan pangan dan pengembangan agribisnis bidang agroindustri adalah adanya industri perberasan.

Upaya mendukung lapangan usaha pertanian adalah berkembangnya usaha-usaha pertanian yaitu berdirinya industri kecil di wilayah potensial pertanian. Output yang dihasilkan yang memiliki keterkaitan dengan pengembangan rantai pasokan.Kegiatannya dimulai penanganan pasca panen hingga pemasaran kepada para konsumen. Hal ini akan berdampak bukan hanya pada pengusaha, namun juga semua lembaga yang terkait dengan perberasan (Salsabilla et al., 2014).

Industri bahan makan salah satunya produk beras merupakan salah satu bahan pangan yang strategis. Salah satu kinerja rantai pasok pada bahan pangan yang berupa produk beras memegang peranan akan terjadinya seluruh proses yaitu, memiliki sistem produksi dan distribusi sampai pada pemasaran merupakan bagian dari sistem rantai pasok (Swastika \& Sumaryanto, 2010).

Berbagai permasalahan yang ditemukan dalam usaha penggilingan padi pada distribusi bahan baku dan produk, karena rantai pasokan komoditas pertanian sangat kompleks dan banyak pelaku dalam kegiatan proses produksi hingga pemasarannya. Pasar adalah salah satu komponen dalam sistem rantai pasok. Manajemen rantai pasokan telah menjadi bagian utama dari sistem manajemen perusahaan, karena banyak manfaat yang terkait dengan rantai pasokan di lingkungan bisnis saat ini.

Gabah kering sebagai bahan baku utama industri penggilingan padi sering terjadi ketidakstabilan antara permintaan dan pasokan, untuk menstabilkan dan kontinyuitas pasokan dibutuhkan perencanaan ketersediaan bahan baku. Rantai pasok penggilingan padi secara sederhana merupakan urutan dalam sebuah rangkaian yang terdiri pemasok, pemroses, distributor atau pengecer dan konsumen dengan bahan baku utamanya komoditas padi. Rantai pasok penggilingan padi akan melibatkan banyak pihak diantaranya petani, pedagang pengepul gabah kering, pedagang pengepul beras, distributor, pengecer dan pihak terkait tidak langsung lainnya. Fenomena-fenomena yang terjadi dan beberapa konsep tentang rantai pasok komoditi pertanian maka perlu adanya kajian tentang bagaimana bentuk rantai pasok usaha penggilingan padi di Kabupaten Kolaka Timur. 


\section{Metode Penelitian}

Ruang lingkup penelitian ini adalah rantai pasok yang berada pada usaha penggilingan padi dengan menggambarkan sistem rantai pasok yang terjadi. Jenis penelitian ini merupakan studi kasus, yakni hanya mengambil satu obyek secara khusus dengan dasar pertimbangan tertentu sebagai suatu kasus. Perolehan data pada studi kasus dapat diperoleh dari satu obyek yang bersangkutan, dengan kata lain dalam studi dikumpulkan dari salah satu sumber (Nawawi, 2003; Nursalam et al., 2019).

Penelitian yang dilakukan termasuk kualitatif deskriptif. Metode wawancara dilakukan kepada pengusaha penggilingan padi yang telah ditentukan sebagai obyek penelitian dan data informasi responden sebagai perwujudan representatif dari objek yang diteliti.Variabel terkait rantai pasok yaitu aliran produk, aliran keuangan dan aliran informasi studi kasus pada agroindustri padi UD. Putra Tunggal yang berada di Kabupaten Kolaka Timur. Aliran produk meliputi : aliran bahan baku/gabah $(\mathrm{kg})$ dan produk/beras $(\mathrm{kg})$. Aliran bahan baku (gabah) dari hulu (upstream) ke hilir (downstream), yaitu dari supplier (petani) hingga sampai ke penggilingan UD. Putra Tunggal. Aliran produk (beras) dari hulu (upstream) ke hilir (downstream), yaitu dari penggilingan UD. Putra Tunggal hingga sampai ke konsumen. Aliran keuangan, mengalir dari hilir ke hulu. Aliran keuangan meliputi : informasi biaya, syarat dan jadwal pembayaran.Aliran informasi, dapat terjadi/mengalir dari hulu ke hilir dan dari hilir ke hulu. Aliran informasi meliputi : informasi harga gabah dan beras $(\mathrm{Rp} / \mathrm{kg})$, kualitas gabah dan beras $(\mathrm{Rp} / \mathrm{kg})$, kuantitas gabah dan beras $(\mathrm{Kg})$, stok gabah dan beras $(\mathrm{kg})$, proses/cara pembayaran, dan distribusi.

Teknik yang digunakan dalam penelitian ini adalah menggunakan metode analisis kualitatif dari hasil wawancara obyek rantai pasok pada usaha penggilingan padi.Secara deskriptif yaitu mengetahui dan menggambarkan bentuk/sistem rantai pasok pada usaha penggilingan padi yaitu: (1) Pelaku rantai pasok, (2) Jumlah saluran, (3) Volume yang melewati antara lembaga, (4) Panjang pendeknya rantai pasok, (5) Pola transaksi akan dianalisis, dan (6) kompleksitas rantai pasok.

\section{Hasil dan Pembahasan}

Usaha penggilingan padi UD.Putra Tunggal berada di wilayah Kolaka Timur. Bahan baku utama penggilingan padi adalah gabah dan beras kupas. Secara umum usaha penggilingan padi tergantung pada musim panen yang dihasilkan oleh petani. Kondisi iklim wilayah Kolaka Timur dan pengairannya yang memadai dengan sistem pengairan tehnis sangat mendukung petani sawah. Petani pada umumnya melakukan budi daya padi sawah yang mengadopsi kebiasaan dan anjuran Dinas Pertanian Tanaman Pangan.

Kolaka timur terdapat dua musim tanam (MT) dalam setahun.Periode musim tanam pertama (MT I) pada bulan Oktober-Maret dan musim tanam kedua (MT II) pada bulan AprilSeptember. Periode musim tanam (MT) dilakukan berdasarkan kalender musim, akan tetapi karena kondisi cuaca yang dipengaruhi perubahan iklim oleh pemanasan global, maka musim tanam terkadang terjadi perubahan (Runtunuwu et al., 2012).

Kondisi wilayah perusahaan juga mengalami perubahan musim tanam (MT). Hasil penelitian (Runtunuwu et al., 2012) menyatakan bahwa, kalender awal musim tanam di daerah Sulawesi tenggara secara umum terjadi dua kali periode musim tanam, akan tetapi dapat berubah akibat iklim yang mempengaruhinya.Menurut BPS tahun 2020, Indonesia mengalami cuaca ekstrem dengan curah hujan tinggi pada Januari-Februari 2019. Banjir terjadi di berbagai daerah, beberapa diantaranya menggenangi lahan sawah.Lalu ada juga cuaca ekstrem berupa kemarau panjang di periode Juli-Desember 2019. Berbagai pengaruh cuaca ekstrem ini berkontribusi pada penurunan luas panen.

Musim tanam yang mengalami perubahan maka, hasil panen padi di wilayah Kolaka Timur tidak dapat memenuhi kebutuhan bagi pengusaha penggilingan padi. Persaingan untuk mendapatkan gabah sebagai bahan baku antara pengusaha penggilingan padi, maka pengusaha melakukan pembelian di daerah lain. Pengusaha penggilingan padi dalam hal ini setidaknya melibatkan seluruh jaringan rantai pasok antara lain petani, pedagang pengepul gabah, pengusaha penggilingan padi lainnya, pedagang besar dan Bulog. Menurut (Swastika \& Sumaryanto, 2010) bahwa, dari sisi rumusan kebijakan dan implementasi, kebijakan industri perberasan harus bersifat simultan dari hulu sampai hilir. Kebijakan industri beras harus mencakup seluruh jaringan rantai pasok, yang setidaknya terdiri atas lima tingkat, yaitu petani, pedagang perantara/pengumpul gabah, penggilingan padi, pedagang beras di sentra produksi, dan pedagang beras di pasar induk perkotaan dan pengecer.

Sistem rantai pasok pada usaha penggilingan padi UD. Putra Tunggal diuraikan secara terperinci yakni ; (1) Pelaku rantai pasok, (2) Jumlah saluran, (3) Volume yang melewati antara lembaga, (4) Panjang pendeknya rantai pasok dan (5) Pola transaksi dan kompleksitas rantai pasok. 


\section{Pelaku Rantai Pasok}

Temuan penelitian menunjukkan bahwa, terdapat beberapa bentuk dan sistem rantai pasok pada usaha penggilingan padi di Kabupaten Kolaka Timur. Bentuk dan sistem rantai pasok tergantung pada para pelaku rantai pasok. Pelaku dalamrantai pasok ini secara garis besar dibagi menjadi dua, yaitu pelaku utama dan pelaku pendukung. (Bahari, 2017) menyatakan bahwa, rantai pasok (supply chain) adalah jaringan perusahaan-perusahaan yang secara bersama-sama bekerja untuk menciptakan dan menghantarkan suatu produk ke tangan pemakai akhir.

\section{Pelaku Utama}

Pelaku utama rantai pasok adalah yang berperan dalam pengadaan barang untuk didistribusikan kepada pengusaha. Beberapa pelaku utama yang terdapat dalam pola rantai pasok usaha penggilingan padi di Kabupaten Kolaka Timur adalah petani, pedagang pengumpul/pengepul gabah, pedagang besar, pedagang pengecer dan Bulog untuk sampai pada industri penggilingan.

Petani memiliki peranan yang sangat besar dalam rantai pasok usaha penggilingan padi. Petani merupakan produsen yang menghasilkan bahan baku utama yaitu berupa gabah untuk didistribusikan kepada pedagang ataupun penggilingan. Harga jual yang diterima petani didasarkan pada keadaan harga gabah pada saat tertentu yang ditentukan oleh pedagang atau pemilik penggilingan dan atas kesepakatan bersama. Kegiatan yang dilakukan petani meliputi proses produksi (on farm). Petani saat ini memiliki suatu pilihan dalam melakukan proses pasca panen yakni, tidak melakukan proses pengeringan. Pengeringan padi setelah panen membutuhkan waktu dan menambah biaya tenaga kerja yang akan mempengaruhi pendapatan petani itu sendiri. Hasil panen dijual secara langsung pada pedagang pengumpul ataupun ke pengusaha penggilingan padi.

Pedagang pengumpul gabah merupakan salah satu lembaga pemasaran yang menjadi anggota rantai pasok gabah. Pedagang pengumpul mendapatkan gabah dari petani di wilayah Sulawesi Tenggara. Kegiatan yang dilakukan pedagang pengumpul meliputi pembelian, pengangkutan, dan penjualan. Keberadaan pedagang pengumpul gabah sangat membantu dalam pengadaan bahan baku pada usaha penggilingan padi.

Usaha penggilingan memiliki peranan yang sangat penting. Kegiatan usaha penggilingan padi di Kabupaten Kolaka Timur dilakukan mulai dari kegiatan pembelian gabah di sekitar wilayah usaha dan daerah - daerah tertentu yang memiliki potensi penghasil gabah. yang kemudian akan diproses menjadi beras sampai pada aktivitas penjualan hasil olahan berupa beras ke konsumen. Ada beberapa cara bisnis yang dilakukan oleh pemilik usaha penggilingan sebagai lembaga pemasar beras yaitu melakukan pembelian gabah dari pedagang pengumpul atau langsung ke petani, sedangkan beras hasil produksinya dipasarkan sesuai dengan permintaan konsumen (pedagang besar, pedagang ecer) yang diterima di gudang perusahaan.

Pedagang besar adalah pelaku yang membeli beras dari pemilik usaha penggilingan langsung yang sudah memiliki ikatan mitra kerja sebelumnya untuk didistribusikan ke pedagang pengecer ataupun langsung ke konsumen. Berbeda halnya dengan pedagang pengecer, pedagang besar membeli beras dalam jumlah yang banyak. Pedagang besar juga memiliki gudang penyimpanan beras untuk memyimpan pasokan beras yang akan disalurkan ke pedagang lainnya.

Pedagang pengecer merupakan lembaga pemasaran yang memiliki peranan didalam mendistribusikan beras. Distribusi dimulai dari pedagang besar ataupun usaha penggilingan. Lembaga ini berhubungan langsung dengan konsumen akhir dalam menjual beras.

Bulog merupakan lembaga yang bertanggung jawab terhadap mekanisme distribusi dan impor beras. Pemilik usaha penggilingan sebagian besar bermitra dengan Bulog karena dianggap menguntungkan karena tidak bersifat mengikat. Kemitraan ini artinya pemilik usaha bebas melakukan penjualan berasnya, pada saat harga beras tinggi ke pihak luar selain Bulog. Sementara Bulog akan membeli beras pemilik dengan harga pembelian pemerintah (HPP) saat harga jatuh di pasaran. Bulog menetapkan kebijakan kenaikan harga pada pembelian gabah di tingkat petani di atas harga pembelian pemerintah (HPP). Hal itu dilakukan untuk menjaga harga di petani tetap menguntungkan lantaran HPP gabah dianggap sudah jauh di bawah harga pasar. Selain itu, Bulog dapat membeli beras yang dihasilkan oleh penggilingan atau penggilingan dapat berperan sebagai mitra giling dari gabah yang dimiliki Bulog. Timisela et al., (2014) menyatakan bahwa, mekanisme rantai pasok agroindustri yang terjadi yaitu terciptanya kolaborasi dan koordinasi diantara pelaku rantai pasok mulai dari hulu sampai ke hilir. Pola aliran rantai pasok yang terdiri dari aliran bahan baku, aliran produk, aliran finansial dan aliran informasi berlangsung baik dan lancar. 


\section{Pelaku Pendukung}

Pelaku pendukung adalah perusahaan yang menyediakan sumber daya, pengetahuan, utilitas atau aset-aset bagi pelaku utama. Pelaku pendukung pada rantai pasok beras ini yaitu produsen kemasan, lembaga pembiayaan (bank) buruh angkut dan buruh di dalam pabrik. Salsabilla dkk. (2014), menunjukkan bahwa adanya keterlibatan semua pihak dalam manajemen rantai pasok pabrik beras yakni, telah melakukan aliran produk, aliran keuangan dan aliran informasi dalam sistem manajemen rantai pasok pasca panen padi.

\section{Jumlah Saluran}

Hasil identifikasi sistem rantai pasok pada UD. Putra Tunggal memiliki 7 (tujuh) saluran yang terdapat pada Gambar 1. Saluran rantai pasok tersebut terdiri dari dua kelompok yakni aliran pemasok bahan baku (gabah) dan aliran distribusi produk (beras). Kelompok pertama saluran adalah; (1) saluran ini menggambarkan, sebahagian petani sebagai pemasok bahan baku (gabah) menjual langsung ke UD. Putra Tunggal, (2) Petani menjual gabahnya ke pedagang pengumpul yang kemudian dijual ke perusahaan, (3) Saluran ini terjadi saat UD. Putra Tunggal kehabisan pasokan dengan membeli bahan baku (beras kupas) di penggilingan padi di wilayah Sulawesi Tenggara dan Sulawesi Selatan dan Bulog.

Saluran kelompok kedua, (4) saluran distribusi dan pemesan beras yakni pedagang besar dari berbagai wilayah Indonesia yang memesan dan langsung membeli ke UD. Putra Tunggal, (5) Pedagang ecer yang berada di wilayah Sulawesi Tenggara merupakan pembeli beras yang langsung membeli ke UD. Putra Tunggal, (6). Saluran ini merupakan alternativ perusahaan dalam menjaga kondisi perusahan dengan melakukan kerjasama dengan Bulog, dan (7) Pada saluran rantai ini adalah perusahaan langsung menjual secara eceran ke konsumen.(Bahari, 2017) menyatakan bahwa, rantai pasok dapat dikelola sebagai satu kesatuan melalui anggota dominan atau, kerja sama dan koordinasi alternatif, melalui sistem kemitraan yang membutuhkan pengembangan dan koordinasi yang baik.

\section{Volume yang Melewati antara Lembaga}

Data yang diperoleh pada UD. Putra Tunggal mengenai jumlah pembelian bahan baku gabah dan penjualan beras, di setiap saluran dengan volume persentase pertahun terdapat pada Gambar 1 yaitu ; (1) Pembelian bahan baku (gabah) di petani sebesar 35\%, (2) Pembelian gabah pada lembaga ini sebesar 50\%, (3) Pembelian bahan baku (beras kupas) di penggilingan lainya dengan volume $15 \%$, (4) Distribusi dan pemesan beras pada UD. Putra Tunggal oleh pedagang besar dengan volume penjualan sebesar 55\%, (5) Penjualan beras pada pedagang ecer sebesar $35 \%$, (6). Bulog merupakan alternativ untuk memperoleh bahan baku (beras kupas) dan penjulan beras sekitar 5\%, dan (7) Penjualan beras yang dilakukan perusahan secara langsung ke konsumen akhir yaitu melalui toko milik perusahaan yang berada di Kolaka Timur dan Kota Kendari sebesar 5\%.

Tabel 1. Rata-rata Volume Pembelian Bahan Baku dan Harga Gabah dan Beras Kupas (Kg) Per Tahun Periode Tahun 2015-2019

\begin{tabular}{llccc}
\hline No & $\begin{array}{c}\text { Volume } \\
\text { Gabah Kering }(\mathrm{Kg})\end{array}$ & $\begin{array}{c}\text { Harga Gabah } \\
(\mathrm{Kg})\end{array}$ & $\begin{array}{c}\text { Volume } \\
\text { Beras Kupas (Kg) }\end{array}$ & $\begin{array}{c}\text { Harga Beras } \\
\text { Kupas }(\mathrm{Kg})\end{array}$ \\
\hline 1 Kolaka/Bulog & - & - & 68.000 & 5.500 \\
2 Sulawesi Selatan & - & - & 218.000 & 6.500 \\
3 Kolaka Timur & 347.500 & 3,895 & - & - \\
4 Bombana & 405.500 & 3,895 & - & - \\
5 Konawe Selatan & 511.500 & 3,895 & - & - \\
6 Konawe & 1.323 .500 & 3,895 & 68.500 & 5.500 \\
\hline
\end{tabular}

Sumber: Data Hasil Penelitian Setelah Diolah, 2020

Tabel 1 menunjukkan bahwa, total volume dalam kilogram pembelian bahan baku gabah dan beras kupas disetiap wilayah. Pengadaan bahan baku gabah tertinggi dengan volume sebesar 1.323.500 Kg diperoleh di Konawe, jumlah volume terendah sebesar $347.500 \mathrm{Kg}$ yang diperoleh di Kolaka Timur. Sedangkan pengadaan bahan baku beras kupas dengan volume tertinggi sebesar 218.000 Kg diperoleh di Sulawesi Selatan (Sidrap dan Pinrang) dan volume terendah sebesar $68.000 \mathrm{Kg}$ diperoleh di Bulog Kolaka. Total volume pengadaan bahan baku yang menunjukkan bahwa, di wilayah perusahaan (Kolaka Timur) bahan baku sangat rendah, yang mengakibatkan pengusaha melakukan pembelian bahan baku di daerah lain.

Aliran distribusi produk (beras) persentase nilai tertinggi sebesar 55\% pertahun terdapat pada aliran pedagang besar, untuk nilai terendah sebesar $5 \%$ pertahun pada aliran konsumen akhir. Aliran distribusi produk (beras) tertinggi pada aliran pedagang besar, hal ini menunjukkan bahwa, pasar beras terbesar adalah di luar wilayah Sulawesi Tenggara (perdagangan antar pulau). 
Sistem rantai pasok terjadi fenomena sangat unik, yaitu perdagangan beras antar pulau. Abidin et.al. (2005) menyatakan bahwa, meskipun dalam wilayah Provinsi Sulawesi Tenggara musim panen, dimana pada waktu yang sama terjadi pemasukan dan pengeluaran beras, meskipun jumlah beras yang masuk jauh lebih besar. Kondisi perdagangan yang terjadi adanya perbedaan musim tanam antara wilayah Sulawesi Selatan dan Sulawesi Tenggara. Beras yang keluar dari wilayah Sulawesi Tenggara (perdagangan antar pulau) banyak dilakukan pada saat musim panen, sementara pemasukan dilakukan pada saat musim paceklik.

Tabel 2 Rata-rata Volume Distribusi dan Harga Beras (Kg) Per Tahun Periode Tahun 2015-2019

\begin{tabular}{clcc} 
No & & Volume Beras $(\mathrm{Kg})$ & Harga Beras $(\mathrm{Kg})$ \\
\hline 1 & Pedagang Besar & 973.442 & 9800 \\
2 & Pedagang Ecer & 619.463 & 9900 \\
3 & Bulog & 88.495 & 9800 \\
4 & Konsumen Akhir & 88.495 & 9900 \\
& Total & 1.769 .895 & \\
\hline
\end{tabular}

Sumber: Data Hasil Penelitian Setelah Diolah, 2020

\section{Panjang Pendeknya Rantai Pasok}

Pola rantai pasok yang terdapat pada Gambar 1 terdiri berbagai pola. Kegiatan rantai pasok yang terdiri dari pengadaan bahan baku (gabah dan beras kupas) dan distribusi produk (beras). Keberlangsungan bisnis usaha penggilingan padi tergantung pada proses produksi, maka harus didukung dengan pasokan bahan baku (gabah dan beras kupas). Kebutuhan bahan baku gabah maupun beras kupas tidak terpenuhi hanya di wilayah perusahaan (Kolaka Timur). Mendapatkan bahan baku merupakan salah satu kegiatan bisnis, yang terjadi adanya suatu persaingan antara UD. Putra Tunggal dengan usaha penggilingan padi lainnya. Proses pengadaan bahan baku juga didasarkan pada beberapa pertimbangan tertentu seperti hubungan kerjasama dan kepercayaan, kesepakatan harga beli, efesien dan efektif proses bisnis usahanya.

Pedagang besar adalah konsumen antara pada UD. Putra tunggal yang berada di berbagai wilayah seperti Sulawesi Selatan, Sulawesi Tenggara, Jawa Timur, Sumatera dan Maluku serta merupakan daerah konsumen beras. Adapun pedagang besar yang terlibat pada masing-masing saluran merupakan mitra kerja yang sudah lama menjalin hubungan kerjasama dan kepercayaan dengan pemilik usaha penggilingan. Setiap daerah yang memiliki potensi produsen padi, akan tumbuh usaha penggilingan padi, yang berkapasitas produksi berasnya sangat besar. Meskipun demikian, pedagang besar yang berada di daerah yang berbeda-beda tetap melakukan pembelian beras pada UD. Putra Tunggal.

Pola sistem rantai pasok yang terjadi adalah perusahaan menjaga kepercayaan dari sisi kualitas, volume dan harga. Pola rantai pasok yang terjadi menunjukkan bahwa, setiap saluran memiliki dampak dan kemungkinan risiko yang berakibat pada risiko keuangan akibat sistem dalam persaingan bisnis. (Astuti, 2012) menyatakan, bahwa beberapa keputusan dalam pengembangan rantai pasok mempunyai karakteristik yang berefek jangka menengah hingga jangka panjang, mengandung risiko dan ketidakpastian sedang hingga tinggi, serta mempunyai konsekuensi yang relatif besar terhadap organisasi yang terlibat. (Jaffee et al., 2010) penelitiannya juga mendukung temuan penelitian ini bahwa, risiko dan ketidakpastian ada di mana-mana dan beragam pada rantai pasokan pertanian. Meskipun pelaku rantai pasokan biasanya saling tergantung dan perlu mengelola beberapa jenis risiko dari sistem penilaian risiko, manajemen risiko, dan kerentanan dalam rantai pasokan pertanian.

\section{Pola Transaksi dan Kompleksitas Rantai Pasok}

Transaksi merupakan persetujuan jual beli (dalam perdagangan) antara dua pihak berupa gabah maupun produknya yaitu beras. Pola transaksi pada rantai pasok pada usaha penggilingan padi di Kabupaten Kolaka Timur memiliki pola transaksi yang berbeda-beda terdiri dari pola transaksi rantai pasok bahan baku (gabah) dan pola transaksi produk (beras). (Bahari, 2017) menyatakan bahwa, rantai pasokan sebagai rangkaian kegiatan fisik dan dalam pengambilan keputusan dihubungkan dengan materi arus informasi, uang dan hak milik yang melintasi batas-batas organisasi.

Berikut akan diuraikan pola transaksi yang terjadi pada saluran rantai pasok. Pola transaksi saluran rantai pasok usaha penggilingan padi, melibatkan beberapa pihak sebagai anggota mata rantai. Rantai pasokan bahan baku (gabah) dan produk (beras) yang terjadi di UD. Putra Tunggal merupakan sebuah proses bisnis. (Bahari, 2017) menyatakan bahwa, rantai pasokan sebuah proses bisnis, dapat dilihat sebagai terstruktur, terukur serangkaian kegiatan yang dirancang untuk menghasilkan output yang ditujukan untuk pelanggan tertentu atau pasar. Pengelolaan rantai pasok juga dinyatakan oleh (Purwatmini, 2015) bahwa, pengelolaan rantai pasok diartikan sebagai pengelolaan berbagai kegiatan dalam rangka memperoleh bahan 
baku (gabah), dilanjutkan dengan proses transformasi melalui pengolahan sehingga menjadi bahan jadi (beras) dan diteruskan dengan pengiriman ke konsumen melalui sistem distribusi.
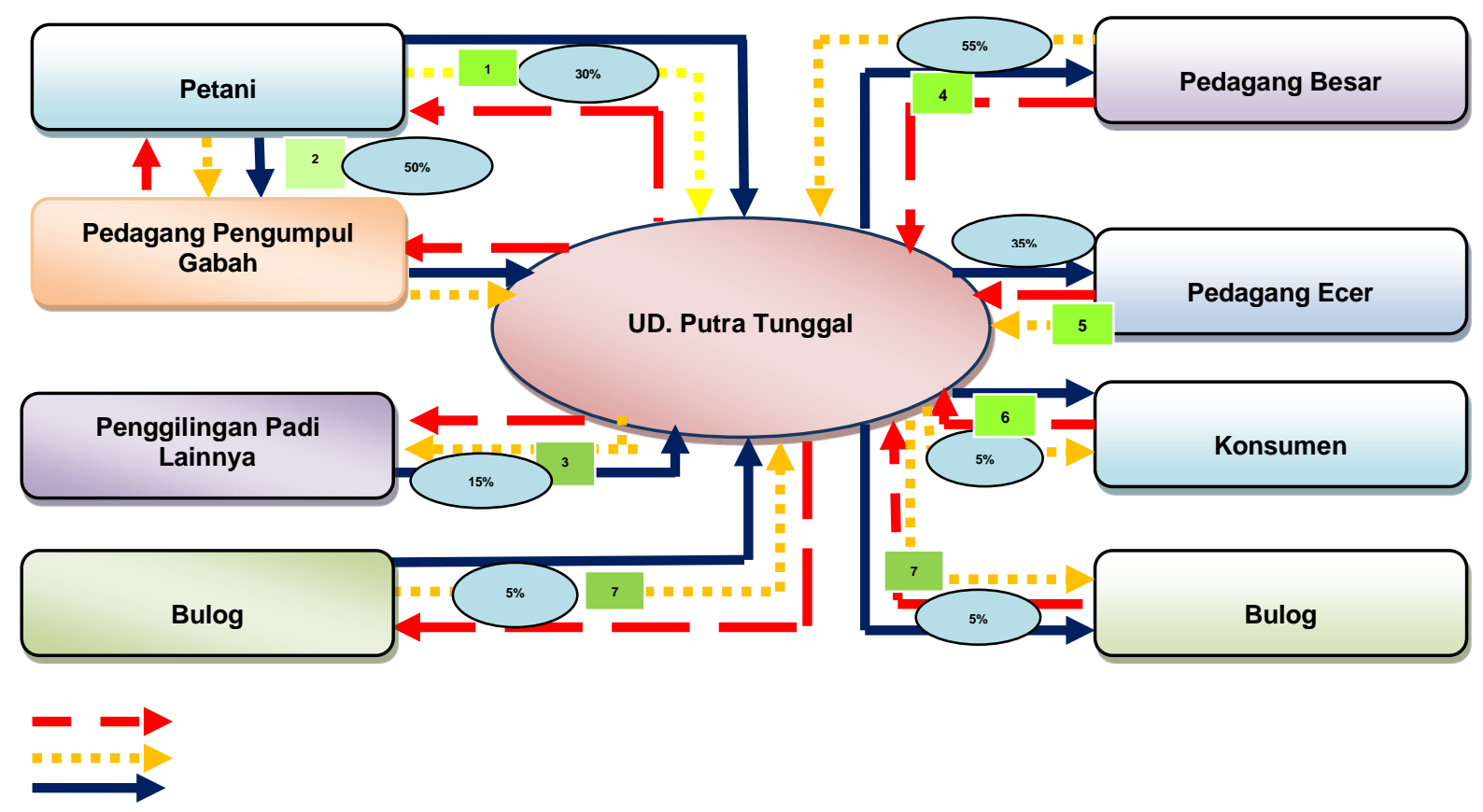

Keterangan gambar :

Aliran uang

Aliran informasi

Aliran barang

Gambar 1. Pola Rantai Pasok pada Usaha Penggilingan Padi di Kabupaten Kolaka Timur Sumber : Data Hasil Penelitian Setelah Diolah, 2020

Rantai pasok menurut (Padangaran, 2016a) bahwa, suatu rentetan kegiatan-kegiatan yang harus dilakukan mulai dari pengadaan bahan baku, pengolahan, pendistribusian barang dan sampai kepada kegiatan pemasaran barang dari produsen untuk sampai ke tangan konsumen. Kegiatan pada usaha penggilingan padi yang terjadi, sejalan dengan pernyataan (Padangaran, 2016b) bahwa, anggota mata rantai yang terlibat antara lain, pemasok bahan baku (gabah) yakni petani, pedagang pengumpul gabah, usaha penggilingan padi lainnya sebagai pemasok beras kupas,pedagang besar, pedagang pengecer, konsumen dan Bulog.

Riset (Simchi-Levi \& Zhao, 2003) juga menyatakan bahwa, seluruh kegiatan agroindustri perlu ditunjang oleh perencanaan dan pelaksanaan yang baik. Untuk lebih jelasnya pola transaksi pada rantai pasok usaha penggilingan padi dapat dilihat pada Gambar 1. Kejelasan dan pengaturan dalam pelaksanaan tata rantai pasokan yang baik dapat menunjang keberhasilan pelaksanaan rantai pasok.

Pola rantai pasok usaha penggilingan padi yang digambarkan pada Gambar 1 ada beberapa pola saluran rantai pasok, terdiri dari dua kelompok yang mempunyai peranan masing-masing yaitu pola distribusi bahan baku (gabah dan beras kupas) dan pola distribusi produk beras poles dengan uraian sebagai berikut;

a) Pola Distribusi Bahan Baku (Gabah dan Beras Kupas)

1) Petani mendapatkan informasi harga langsung dari perusahaan untuk melakukan penjualan hasil panen berupa gabah dengan sistem pembayaran di tempat setelah dilakukan penimbangan di gudang sebesar $35 \%$ pertahun. Perusahaan melakukan pembelian langsung ke petani dengan cara, gabah diantar langsung ke gudang dan pengusaha mengambil di tempat (sawah) saat panen. Metode ini dilakukan karena persaingan antar pedagang dan pengusaha lain untuk mendapatkan bahan baku, sehingga menimbulkan dampak penambahan biaya yang harus dikeluarkan dan ditanggung oleh perngusaha.

2) Petani juga melakukan penjualan hasil panen gabah tersebut ke Pedagang pengepul. Pola ini terjadi pada petani yang mempunyai jumlah luasan yang sedikit, dan sebagian petani memiliki hutang terhadap pedagang (sistem ijon). Sistem pengembalian hutang pada saat panen dengan membayar menggunakan gabah. Perusahaan mempunyai risiko tidak 
mendapatkan gabah/bahan baku, pedagang pengepul mempunyai pilihan untuk menjual ketempat pengusaha lain ataupun pedagang besar lainnya yang disebabkan persaingan harga.

3) Pedagang pengumpul melakukan penjualan gabah sebesar $50 \%$ pertahun. Perusahaan dalam melakukan pembelian gabah kepada pedagang pengepul dengan sistem pemberian fee. Perhitungan yang dikeluarkan di setiap pembelian dengan memperhitungkan jumlah yang akan diberikan, untuk setiap kelebihan dari harga gudang perkilogramnya. Sistem pemberian fee dilakukan, untuk mendapatkan bahan baku, meskipun menambah biaya sebagai dampak persaingan dengan mengeluarkan biaya tambahan diluar harga dasar pembelian.

4) UD. Putra Tunggal melakukan pembelian beras kupas yang akan diproses untuk permintaan beras poles. Pembelian ini dilakukan apabila perusahaan mengalami kondisi terdesak akibat adanya permintaan beras poles, akan tetapi terjadi kekurangan bahan baku di gudang. Perusahaan melakukan pembelian beras kupas di Bulog sebesar 5\% pertahun dan penggilingan padi lainnya yang berada di wilayah Sulawesi Tenggara dan Sulawesi Selatan (Sidrap dan Pinrang) sebesar 15\% pertahun. Pembelian beras kupas mempunyai risiko mengeluarkan biaya yang agak tinggi, akan tetapi risiko ini tetap diambil, karena menjaga kepercayaan konsumen atau pelanggan yang telah lama bekerjasama dengan perusahaan.

b) Pola Distribusi Produk (Beras)

1) UD. Putra Tunggal melakukan penjualan beras berdasarkan pesanan pedagang besar berasal dari Surabaya, Salatiga, Medan, Semarang, dan Maluku. Sistem penjualannya yaitu, antara perusahaan dan pedagang menyepakati harga, dengan kesepakatan yang telah ditetapkan bersama. Ketetapan harga beras di gudang di luar dari, seluruh risiko yang terjadi selama proses pengangkutan. Biaya pengangkutan ditanggung oleh pedagang pemesan (beras dibeli dari gudang perusahaan). Pengangkutan beras diproses setelah pemesan/pedagang besar melakukan pembayaran melalui sistem transfer. Sistem penjualan beras ini sebesar $55 \%$ pertahun.

2) UD. Putra Tunggal juga melakukan penjualan beras berdasarkan pesanan pedagang ecer yang berasal dari wilayah Sulawesi Tenggara. Sistem penjualannya yaitu, perusahaan dan pedagang menyepakati harga dengan ketetapan harga gudang. Sedangkan biaya pengangkutan ditanggung oleh pedagang pemesan (beras dibeli dari gudang perusahaan), dan seluruh risiko selama proses pengangkutan ditanggung oleh pedagang pemesan. Proses pengangkutan beras dari gudang, dilakukan setelah dana pembelian di transfer, penjualan beras ini sebesar 35\% pertahun.

3) UD. Putra Tunggal juga melakukan penjualan ke konsumen langsung, melalui toko milik perusahaan yang berada di Kecamatan Ladongi dan Kota Kendari sebesar 5\% pertahun. Perusahaan tidak mengeluarkan biaya risiko penjualan, karena harga jual yang telah ditetapkan ke konsumen telah diperhitungkan. Harga jual beras merupakan perhitungan dari harga di gudang dengan biaya- biaya yang akan dikeluarkan.

4) UD. Putra Tunggal melakukan penjualan beras dengan meminta ke Bulog untuk membeli berasnya sebesar $5 \%$ pertahun. Tujuan dari penjualan adalah menjaga agar perusahaan tidak merugi. Kerugian berasal dari, akibat turunnya harga beras dipasaran pada waktuwaktu tertentu, sedangkan harga pembelian bahan baku yang sangat tinggi.

Berdasarkan uraian pada Gambar 1 bahwa, pola saluran rantai pasok usaha penggilingan padi sangat komplek. Terdapat dua kelompok pola saluran rantai pasok yaitu, pola distribusi bahan baku (gabah dan beras kupas) dan pola distribusi produk (beras). Pola saluran distribusi bahan baku (gabah dan beras kupas) terdiri dari petani, pedang pengepul gabah dan perusahaan penggilingan padi lainnya sebagai pemasok beras kupas dan Bulog. Pola tersebut disebabkan perusahaan untuk mendapatkan bahan baku serta menjamin keberlanjutan dalam menjalankan produksi. Secara grafis persentase aliran barang pertahun pada rantai pasok usaha penggilingan padi UD.Putra Tunggal dapat dilihat pada Gambar 2.

Gambar 2 grafik persentase per tahun aliran barang pola rantai pasok usaha penggilingan padi menunjukkan bahwa, terdapat aliran pengadaan bahan baku gabah dan beras kupas. Nilai tertinggi sebesar $50 \%$ per tahun terdapat pada aliran pedagang pengumpul, sedangkan nilai terendah sebesar 5\% per tahun pada aliran Bulog.

Pada aliran rantai pasok menggambarkan bahwa sistem rantai pasok gabah dikuasai oleh pedagang pengumpul gabah. Persaingan antara perusahaan untuk mendapatkan bahan baku melakukan beberapa strategi yakni, salah satu dengan memberikan insentif. Sedangkan aliran distribusi produk (beras) persentase nilai tertinggi sebesar $55 \%$ per tahun terdapat pada aliran pedagang besar, untuk nilai terendah sebesar $5 \%$ per tahun pada aliran konsumen akhir. Aliran 
distribusi produk (beras) tertinggi pada aliran pedagang besar, hal ini menunjukkan bahwa, pasar beras terbesar adalah di luar wilayah Sulawesi Tenggara (perdagangan antar pulau).

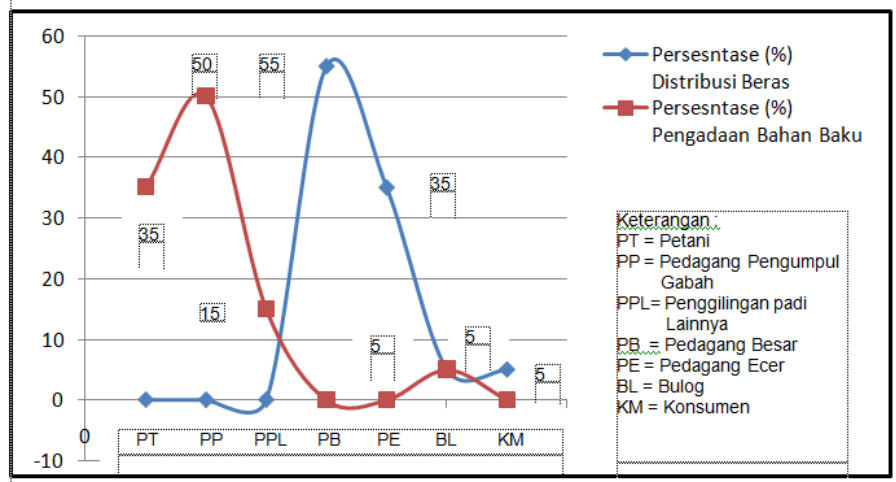

Gambar 2 Grafik Persentase Per tahun Aliran Barang Rantai Pasok Usaha Penggilingan Padi UD. Putra Tunggal Sumber : Data Hasil Penelitian Setelah Diolah, 2020

Sistem rantai pasok terjadi fenomena sangat unik, yaitu perdagangan beras antar pulau.(Idris \& Syam, 2005) menyatakan bahwa, meskipun dalam wilayah Provinsi Sulawesi Tenggara musim panen, dimana pada waktu yang sama terjadi pemasukan dan pengeluaran beras, meskipun jumlah beras yang masuk jauh lebih besar. Kondisi perdagangan yang terjadi adanya perbedaan musim tanam antara wilayah Sulawesi Selatan dan Sulawesi Tenggara. Beras yang keluar dari wilayah Sulawesi Tenggara (perdagangan antar pulau) banyak dilakukan pada saat musim panen, sementara pemasukan dilakukan pada saat musim paceklik.

Aliran rantai pasok pengadaan bahan baku perusahaan tidak dapat bergantung pada musim tanam/hasil panen di wilayah perusahaan (Kabupaten Kolaka Timur). Secara umum musim tanam hanya dua kali dalam setahun, yaitu pada periode musim tanam Oktober-Maret dan April-September. Bahan baku gabah dan beras kupas diperoleh diberbagai wilayah yang memiliki potensi padi antara lain Konawe, Konawe Selatan, Bombana, Sulawesi Selatan dan Bulog Kolaka. Total volume pengadaan bahan baku periode tahun 2015-2019 dapat dilihat pada Gambar 3.

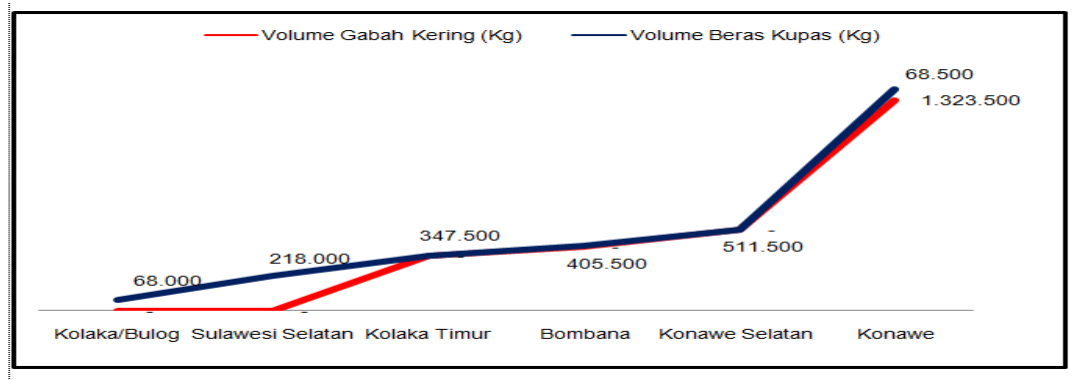

Gambar 3 Grafik Total Volume (Kg) Pengadaan Bahan Baku Periode Tahun 2015-2019 Sumber : Data Hasil Penelitian Setelah Diolah, 2020

Berdasarkan grafik volume pengadaan bahan baku berupa gabah dan beras kupas diperoleh data selama periode tahun 2015-2019 tertuang pada Gambar 3. Data menunjukkan bahwa, total volume dalam kilogram pengadaan bahan baku gabah dan beras kupas disetiap wilayah. Pengadaan bahan baku gabah tertinggi dengan volume sebesar $1.323 .500 \mathrm{Kg}$ diperoleh di Konawe, jumlah volume terendah sebesar $347.500 \mathrm{Kg}$ yang diperoleh di Kolaka Timur. Sedangkan pengadaan bahan baku beras kupas dengan volume tertinggi sebesar $218.000 \mathrm{Kg}$ diperoleh di Sulawesi Selatan (Sidrap dan Pinrang) dan volume terendah sebesar $68.000 \mathrm{Kg}$ diperoleh di Bulog Kolaka. Total volume pengadaan bahan baku yang menunjukkan bahwa, di wilayah perusahaan (Kolaka Timur) bahan baku sangat rendah, yang mengakibatkan pengusaha melakukan pembelian bahan baku di daerah lain.

Sistem rantai pasok pada usaha penggilingan padi mekanismenya dimulai dari hulu hingga ke hilir, yaitu dari petani, pedagang pengumpul, usaha penggilingan lainnya (pemasok beras kupas), usaha penggilingan padi (pemasok beras), pedagang besar, pedagang pengecer, bulog hingga sampai pada konsumen akhir. Kompleksnya rantai pasok mengakibatkan adanya kemungkinan potensi risiko keuangan. 
Kompleksitas tersebut adalah anggota mata rantai yang tersusun mempunyai peran masing-masing.Tingkat kompleksitas anggota mata rantai pada usaha penggilingan padi mengakibatkan potensi risiko keuangan dan ketidakpastian keberlanjutan usaha.Pola transaksi rantai pasok pada perusahaan menunjukkan bahwa, pada kegiatan pengadaan, pengangkutan bahan baku (gabah dan beras kupas) merupakan proses kegiatan transaksi yang memiliki dampak dan kemungkinan timbulnya risiko.

Perusahaan melakukan transaksi pengadaan bahan baku dengan menanggung dampak dari keseluruhan risiko dalam persaingan bisnis, yang berakibat pada risiko keuangan. Pemilihan pola transaksi pada rantai pasok oleh pemilik usaha penggilingan didasarkan pada beberapa pertimbangan tertentu seperti, hubungan kerjasama dan kepercayaan, kesepakatan harga beli, sistem kerjasama, efesien dan efektif proses bisnis usahanya.

Tingkat kompleksitas rantai pasok pada usaha penggilingan padi sejalan dengan penelitian (Zulkifli, 2017) yang menyatakan bahwa, rantai pasokan pada komoditas pertanian sangat kompleks, karena banyak pelaku dan kegiatan dalam proses produksi. (Pujawan \& ER, 2010) menyatakan bahwa, kompleksitas struktur rantai pasok diketahui dapat mengurangi kinerja operasional, mempersulit pengambilan keputusan, dan memicu gangguan-gangguan antar pihak.

Keberadaan banyak pihak dalam sebuah rantai pasok dapat meningkatkan potensi sebuah konflik diantaranya. Pihak-pihak yang berada dalam sistim rantai pasok tersebut seringkali memiliki kepentingan yang berbeda-beda. Sedangkan hasil penelitian (Astuti et al., 2012) berlawanan dengan temuan penelitian ini bahwa, peningkatan keterlibatan beberapa lembaga terkait dapat mendukung penguatan finansial dan kinerja rantai pasok.

Kompleksitas struktur rantai pasok usaha penggilingan padi sejalan dengan pendapat (Pujawan \& ER, 2010) bahwa, struktur rantai yang komplek diketahui dapat mengurangi kinerja operasional, mempersulit pengambilan keputusan, dan memicu gangguan-gangguan antar pihak yang berdampak pada ketidakpastian dan risiko usaha. Keberadaan banyak pihak dalam sebuah rantai pasok meningkatkan potensi konflik, karena memiliki kepentingan yang berbeda-beda.

Kompleksitas rantai pasok usaha penggilingan padi dipengaruhi oleh ; (1) Banyaknya jumlah informasi, barang, dan aliran dana antara pemasok, pabrik, dan distributor, (2) Anggota rantai pasok yang juga merupakan anggota rantai pasok lain, dan (3) Setiap anggota rantai memiliki tujuan tersendiri. (Bahari, 2017) juga menegaskan bahwa, rantai pasokan sebagai rangkaian kegiatan fisik dan dalam pengambilan keputusan dihubungkan dengan materi dan arus informasi, uang dan hak milik yang melintasi batas-batas organisasi.

Pola rantai pasok usaha penggilingan padi di Kolaka Timur sejalan dengan pernyataan (Vorst, 2004) bahwa, manajemen rantai pasok adalah keterpaduan perencanaan, implementasi, koordinasi, dan pengendalian semua proses dan kegiatan bisnis untuk memproduksi dan mengirimkan produk secara efisien serta memenuhi kebutuhan pasar.

Sistem yang terjadi pada usaha penggilingan padi, bertentangan dengan hasil penelitian (Pujawan, 2005) yang menyatakan bahwa, petani sebagai penanam/produsen juga sering kali hanya mempunyai kedudukan sebagai price taker saja. Penentu harga biasanya adalah pedagang pengumpul ataupun pedagang tingkat yang lebih besar (kecamatan, antar pulau, dan eksortir/importir) (Prihantini, 2015). Sedangkan yang terjadi temuan pada penelitian ini, sebahagian petani sebagai price maker, yang mempunyai kekuatan dan peranan dalam menentukan harga.Petani dapat memilih serta menentukan dimana akan dijual hasil produksinya (gabah) sesuai dengan harga yang disepakati bersama. Karena sebahagian petani tidak terikat sistem hutang, sebagai permodalan untuk usahataninya dengan pihak pedagang dan pengusaha.

\section{Simpulan}

Berdasarkan hasil dan pembahasan sebelumnya maka dapat disimpulkan bahwa, Sistem rantai pasok pada usaha penggilingan padi terdiri atas 2 kelompok yaitu Saluran pemasok bahan baku (gabah) dan Saluran distribusi produk (beras). Saluran pemasok bahan baku (gabah) didominasi oleh saluran Petani - Pedagang Pengumpul Gabah - Perusahaan yang mempunyai pangsa $50 \%$ dari total volume pembelian pertahun. Sedangkan saluran distribusi produk (beras) didominasi oleh saluran Perusahaan - Pedagang Besar yang mempunyai pangsa 55\% dari total volume penjualan pertahun. Kompleksnya rantai pasok mengakibatkan adanya kemungkinan potensi risiko keuangan. Rantai pasokan terbanyak dalam volume dan prosentase $(>50 \%)$ dilalui produk yaitu dari petani, pedagang pengumpul gabah, UD Putra Tunggal, dan pedagang besar. 


\section{Pustaka}

Astuti, R. (2012). Pengembangan rantai pasok buah manggis di kabupaten Bogor, Jawa Barat. http:// repository.ipb.ac.id/handle/123456789/55153

Astuti, R., Marimin, Poerwanto, R., Machfud, \& Arkeman, Y. (2012). Kebutuhan Dan Struktur Kelembagaan Rantai Pasok Buah Manggis Studi Kasus Rantai Pasok Di Kabupaten Bogor. International Research Journal of Business Studies,3(1). https://doi.org/10.21632/IRJBS.3.1.48

Bahari. (2017). Pemasaran Produk Pertanian: Analisis Grafik dan Kuantitatif. Universitas Halu Oleo Press. Kendari

Idris, Z. A., \& Syam, A. (2005). Dinamika Perberasan di Sulawesi Tenggara. SOCA: Jurnal Sosial Ekonomi Pertanian, 5(3), 1-11. https://ojs.unud.ac.id/index.php/soca/article /view/4108

Jaffee, S., Siegel, P., \& Andrews, C. (2010). Rapid Agricultural Supply Chain Risk Assessment: A Conceptual Framework FARM-D. The World Bank. https://www.farm-d.org/document/rapidagricultural-supply-chain-risk-assessment-a-conceptual-framework/

Nawawi. (2003). Metode Penelitian Bidang Sosial. Universitas Gadjah Mada Press. Yogjakarta.

Nursalam, L. O., Arisona, A., Harudu, L., Harianto, E., \& Kasmiati, S. (2019). Mapping of Subsurface Geological Structure and Land Cover Using Microgravity Techniques for Geography and Geophysic Surveys: A Case Study of Maluri Park, Malaysia. 4(3), 280-290. https://doi.org/10.19184/geosi.v4i3.13738. 2614-8528.

Padangaran, A. M. (2016a). Analisis Kuantitatif Pembiayaan Perusahaan Pertanian. IPB Press. Bogor. ISBN:978-979-493-547-7

Padangaran, A. M. (2016b). Manajemen Perusahaan Pertanian Teori dan Aplikasi. Program Studi Agribisnis. Universitas Halu Oleo. Kendari. https://www.google.com/search?q $=$ buku+manajemen+perusahaan+teori+dan+aplikasi+ayub+m+padangaran+2016\&client

Prihantini, C. I. (2015). Efisiensi Saluran Pemasaran Garam Rakyat di Desa Padelegan, Kecamatan Pademawu, Kabupaten Pamekasan, Madura, Jawa Timur [Institut Pertanian Bogor]. http:// repository.ipb.ac.id/handle/123456789/76781

Pujawan, I. N. (2005). Supply Chain Management. Penerbit Guna Widya. Surabaya. ISBN: 978979-29-6664-0

Pujawan, I. N., \& ER, M. (2010). Supply Chain Management Volume 2. Penerbit Guna Widya. Surabaya. ISBN: 978-979-29-6664-0

Purwatmini, N. (2015). Peran Manajemen Rantai Pasokan ("Supply Chain Management") Bagi Industri Kreatif Berbasis Industri Keramik. Jurnal Administrasi Kantor, 3(2), 525-538. https://ejournal-binainsani.ac.id/index.php/JAK/article/view/246

Runtunuwu, E., Syahbuddin, H., Ramadhani, F., \& Nugroho, W. T. (2012). Dinamika Kalender Tanam Padi di Sulawesi The Dynamics of Paddy Planting Time in Sulawesi. JURNAL PANGAN, 21(2), 113-124. https://doi.org/10.33964/JP.V21I2.309

Salsabilla, S. M., Wibowo, R., \& Agustina, T. (2014). Analisis Manajemen Rantai Pasok (Supply Chain Management) Padi Pasca. http://repository.unej.ac.id/handle/123456789 /69534

Saragih, B. (2010). Agribisnis paradigma baru pembangunan ekonomi berbasis pertanian. http://repository.ipb.ac.id/handle/123456789/42677

Simchi-Levi, D., \& Zhao, Y. (2003). The value of information sharing in a two-stage supply chain with production capacity constraints. Naval Research Logistics (NRL), 5O(8), 888-916. https://doi.org/10.1002/NAV.10094

Suryana, A. (2014). Menuju Ketahanan Pangan Indonesia Berkelanjutan 2025: Tantangan dan $\begin{array}{lllll}\text { Penanganannya. Forum Penelitian Agro Ekonomi, } & 32(2), & 123 .\end{array}$ https://doi.org/10.21082/fae.v32n2.2014.123-135

Swastika, D. K. S., \& Sumaryanto. (2012). Rantai pasok beras di Indonesia (kasus Provinsi Jabar, Kalbar, dan Kalsel). In: Bunga Rampai Rantai Pasok Komoditas Pertanian di Indonesia. IPB Press. Bogor.

Timisela, N.R. 2013. Manajemen Rantai Pasok dan Kinerja Agroindustri Berbasis Pangan Lokal Serta Strategi Pengembangannya. Disertasi Program Pascasarjana Fakultas Pertanian Universitas Gadjah Mada. Yogyakarta.

Vorst, V. D. J. G. A. J. (2004). Supply Chain Management: Theory and Practices, The Emerging World of Chains \& Networks. Elsevier. https://edepot.wur.nl/357992

Wahyudi, A. F., Jamil, A. S., Zainuddin, A., Rifin, A., Utami, A. D., Fariyanti, AnnaKrisnamurti, Krisnamurthi, B., Pratiwi, C. P., Rachmina, D., Feryanto, Harianto, Malau, L. R. E., Baga, L. M., Tinaprilla, N., Asmarantaka, R. W., Nurmalina, R., Suharto, Sarianti, T., Dewi, T. G., Putri, T. A., \& Muflikh, Y. N. (2017). Menuju Agribisnis Insonesia yang Berdaya Saing. In B. Krisnamurthi \& Harianto (Eds.), Agribusiness Series. Departemen Agribisnis Fakultas Ekonomi dan Manajemen Institut Pertanian Bogor. Bogor. 
Zulkifli. (2017). Assessment Supply Chain Performance and Risk of Agricultural Commodities in South of Sulawesi. International Journal of Scientific Research and Management, 05(11), 7540-7544. https://doi.org/10.18535/ijsrm/v5i11.24 